\title{
Analisis Laporan Keuangan Sebagai Alat Pengukur Kinerja Keuangan Pada PT. Perusahaan Gas Negara (Persero) Tbk Yang Terdaftar di Bursa Efek Indonesia
}

\author{
Juni Darwin \\ Akuntansi, Fakultas Ekonomi Universitas PGRI Palembang \\ email: junidarwin@univpgri-palembang.ic.id
}

\begin{abstract}
ABSTRAK
Data yang diamati merupakan laporan posisi keuangan dan laporan laba rugi komprehensif pada tahun 2015 sampai 2017. Analisis data dan pembahasan dilakukan dengan menggunakan metode deskriptif kualitatif, yaitu menerangkan dengan cara menghitung rasio-rasio yang ada diperusahaan dengan menggunakan rumus Return On Equity (ROE), Return On Investment (ROI), Current Ratio, Cash Ratio, Collection Periods (CP), Perputaran Persediaan (PP), Perputaran Total Asset Turn Over (TATO), Ratio total modal sendiri terhadap total aset. Hasil pembahasan dapat diketahui bahwa kinerja keuangan PT Perusahaan Gas Negara (Persero) Tbk dalam tiga tahun terakhir ini dalam keadaan kurang sehat. Hal tersebut terjadi dikarenakan pendapatan perusahaan pada tiga tahun mengalami penurunan dan laba perusahaan juga mengalami penurunan.
\end{abstract}

Kata Kunci : Kinerja, Laporan Keuangan.

\section{A. Latar Belakang}

Laporan keuangan yang disusun oleh suatu perusahaan dapat digunakan sebagai alat pengambilan keputusan manajerial internal maupun bagi pihak eksternal perusahaan. Laporan keuangan perusahaan dapat dianalisis menggunakan beberapa rasio keuangan, dengan adanya analisis laporan keuangan tersebut dapat diketahui keadaan dan perkembangan perusahaan yang telah dicapai oleh perusahaan diwaktu yang lalu maupun diwaktu yang sedang berjalan baik itu badan usaha swasta maupun badan usaha milik negara.

Laporan keuangan yang telah dianalisis tersebut dapat digunakan sebagai alat bantu untuk pengambilan keputusan manajerial perusahaan. Menurut Munawir (2014:2), laporan keuangan pada dasarnya adalah hasil dari proses akuntansi yang dapat digunakan sebagai alat untuk berkomunikasi antara data keuangan atau aktivitas suatu perusahaan dengan pihak-pihak yang berkepentingan dengan data atau aktivitas perusahaan tersebut. Laporan keuangan perusahaan yang disajikan harus menggambarkan posisi keuangan yang sebenarnya, relavan dan dapat dipertanggungjawabkan keakuratannya.

Penilaian kinerja perusahaan dapat dilakukan dengan menganalisis laporan keuangan yang telah disaji oleh perusahaan. Menurut Fahmi (2014:2), kinerja keuangan adalah suatu analisis yang dilakukan untuk melihat sejauh mana suatu perusahaan telah melaksanakan dengan menggunakan aturan-aturan pelaksanaan keuangan secara baik dan benar. Dalam penganalisisan laporan keuangan dapat dilakukan dengan menggunakan beberapa rasio keuangan. Menurut Prastowo (2015:80), rasio keuangan adalah alat analisis yang dapat memberikan jalan keluar dan menggambarkan simptom 
(gejala-gejala yang tampak) suatu keadaan.

Untuk dapat mengetahui perkembangan perusahaan maka perusahaan harus mengadakan analisis laporan keuangan perusahaan tersebut. Dengan menganalisis laporan keuangan tersebut maka akan mendapatkan informasi-informasi yang berhubungan dengan posisi keuangan dan hasil-hasil yang telah dicapai oleh perusahaan serta informasi yang berhubungan dengan pengambilan keputusan yang akan dilakukan oleh manajerial perusahaan.

Kinerja suatu perusahaan dapat diukur dari beberapa aspek seperti aspek keuangan dan aspek non keuangan. Ditinjau dari aspek keuangan, kinerja keuangan dapat diukur melalui penganalisisan terhadap laporan keuangan perusahaan yang akan memberikan informasi penting bagi perusahaan mengenai posisi keuangan perusahaan, sedangkan dari aspek non keuangan, kinerja perusahaan dapat dinilai dari kualitas kerja para karyawan, tingkat kedisiplinan karyawan, ketepatan pemberian wewenang kerja kepada karyawan serta kesejahteraan para karyawan dan tingkat produktivitas.

Penilaian dari aspek non keuangan akan berbeda karena hasil dari penilaian yang dilakukan pendapatnya muncul dari penilai tersebut. Hal ini akan sulit untuk dilakukan karena akan menghasilkan pendapat yang mungkin berbeda pada tiap penilai, sedangkan jika penilaian dilakukan dengan menggunakan analisis rasio keuangan terhadap laporan keuangan maka hasilnya akan sama.

BUMN merupakan suatu badan usaha yang dimiliki oleh pemerintah. Definisi BUMN menurut Undangundang nomor 19 tahun 2003 tentang BUMN adalah badan yang seluruh atau sebagian besar modalnya dimiliki oleh negara melalui penyertaan secara langsung yang berasal dari kekayaan negara dipisahkan.

Pasal 1 ayat 2 menyatakan bahwa perusahaan perseroan adalah BUMN yang berbentuk perseroan terbatas yang modalnya terbagi dalam saham yang seluruh atau paling sedikit $51 \%$ sahamnya dimiliki oleh Negara Republik Indonesia yang tujuan utamanya mengejar keuntungan.

PT Perusahaan Gas Negara (Persero) Tbk disingkat PGN adalah Badan Usaha Milik Negara (BUMN) yang bergerak di bidang transmisi dan distribusi gas bumi. PGN merupakan perusahaan nasional Indonesia terbesar di bidang transportasi dan distribusi gas bumi yang berperan besar dalam pemenuhan gas bumi domestik.

Perusahaan dalam menjalankan usahanya memerlukan dana yang cukup banyak dimana dalam penggunaan dan pengelolaannya diperlukan pelaporan data yang akurat. Rasio keuangan merupakan salah satu alat yang dapat digunakan untuk mengukur kinerja perusahaan melalui penganalisisan laporan keuangan yang telah disusun oleh manajerial perusahaan.

Laporan keuangan yang dipublikasikan oleh PT Perusahaan Gas Negara (Persero) Tbk belum menghitung rasio-rasio menurut penilaian dasar yang tercantum dalam Keputusan Menteri BUMN Nomor: KEP-100/MBU/2002.

Laporan keuangan perusahaan tersebut baru menampilkan hasil dari perhitungan beberapa rasio dan masih ada rasio yang belum dihitung. Dalam laporan keuangan periode 2015 sampai 2017 rasio yang sudah dihitung adalah rasio lancar (Current Ratio), sedangkan pada Return On Equity (ROE), Return On Investment (ROI), 
Cash Ratio, Collection Periods (CP), Perputaran Persediaan (PP), Perputaran Total Aset Turn Over (TATO), Rasio Total Modal Sendiri Terhadap Total Asset belum dilakukan perhitungan oleh perusahaan.

Perhitungan dari rasio yang belum dihitung diharapkan dapat memberikan gambaran mengenai kinerja keuangan PT Perusahaan Gas Negara (Persero) Tbk selama periode 2015 sampai 2017 berdasarkan Kriteria Penilaian Keputusan Menteri BUMN Nomor: KEP-100/MBU/2002.

\section{B. Rumusan Masalah}

Berdasarkan uraian pada latar belakang, maka rumusan masalah yang terdapat dalam penelitian ini adalah "Bagaimana kinerja laporan keuangan pada PT Perusahaan Gas Negara (Persero) Tbk yang terdaftar di Bursa Efek Indonesia periode 2015 sampai 2017?"

\section{Metode Penelitian}

Metode yang akan digunakan dalam penelitian ini, yaitu dengan menggunakan metode deskriptif kualitatif.

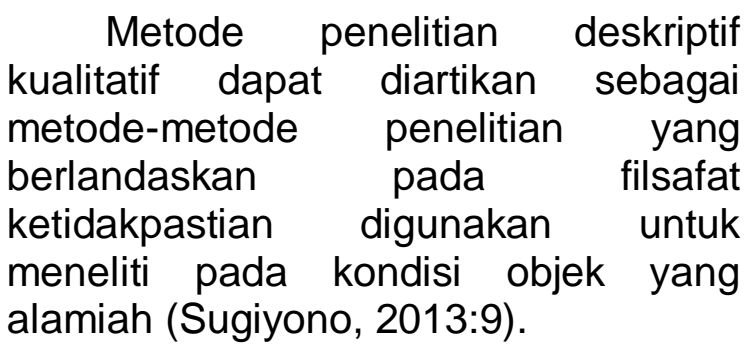

\section{Populasi dan Sampel}

1) Populasi

Menurut Sugiyono (2013:80), populasi adalah wilayah generalisasi yang terdiri atas : objek/subjek yang menpunyai kualitas dan karakteristik tertentu yang diterapkan oleh peneliti untuk dipelajari dan kemudian ditarik kesimpulannya.

Populasi dalam penelitian ini adalah laporan keuangan pada
PT Perusahaan Gas Negara (Persero) Tbk periode 2015 sampai 2017.

2) Sampel

Menurut Sugiyono (2013:81), sampel adalah bagian dari jumlah dan karakteristik yang dimiliki oleh populasi tersebut.

Sampel yang digunakan dalam penelitian ini adalah laporan keuangan PT Perusahaan Gas Negara (Persero) Tbk periode 2015 sampai 2017, yaitu laporan laba/rugi dan laporan neraca.

\section{E. Teknik Pengumpulan Data}

Menurut Sugiyono (2013:224), teknik pengumpulan data merupakan langkah yang paling strategis dalam penelitian, karena tujuan utama dari penelitian adalah mendapatkan data.

Dalam penelitian ini penulis menggunakan teknik pengumpulan data yaitu dokumentasi. Dokumentasi adalah teknik yang dipakai penulis dengan cara mengumpulkan data dengan cara melihat catatan, lampiran dan arsip yang ada pada objek yang diteliti berupa neraca dan laporan laba/rugi pada PT Perusahaan Gas Negara (Persero) Tbk periode 2015 sampai 2017.

\section{F. Teknik Analisis Data}

Menurut Sugiyono (2013:244), analisis data adalah proses mencari dan menyusun secara sistematis data yang diperoleh dari hasil wawancara, catatan lapangan, dan dokumentasi, dengan cara mengorganisasikan data ke dalam kategori, menjabarkan ke dalam unit-unit, melakukan sintesa, menyusun ke dalam pola, memilih mana yang penting dan yang akan dipelajari, dan membuat kesimpulan sehingga mudah dipahami oleh diri sendiri maupun orang lain.

$\begin{array}{cc}\text { Teknik } & \text { analisis data yang } \\ \text { digunakan } & \text { adalah }\end{array}$ 
menggunakan pendekatan metode deskriptif kualitatif, yaitu menerangkan dengan cara menghitung rasio-rasio yang ada di perusahaan dengan menggunakan rumus-rumus tertentu dan memberikan uraian mengenai hasil penelitian.

\section{G. Hasil Penelitian}

1. Analisis Perhitungan Kinerja Keuangan

PT Perusahaan Gas Negara (Persero) Tbk termasuk BUMN maka dalam melakukan penelitian menggunakan rasio dan kriteria yang telah tercantum dalam Keputusan Menteri BUMN Nomor: KEP100/MBU/2002 rasio yang digunakan adalah ROE, ROI, Cash Ratio, Current Ratio, Collection Periods, Perputaran Persediaan, Perputaran Total Aset, dan Rasio Total Modal Sendiri Terhadap Total Aset. Dari delapan rasio yang diperhitungkan, laporan keuangan PT Perusahaan Gas Negara (Persero) Tbk baru menghitung Current Ratio.

Rasio yang belum dihitung antara lain ROE, ROI, Cash Ratio, Collection Periods, Perputaran Persediaan, Perputaran Total Aset, dan Rasio Total Modal Sendiri Terhadap Total Aset. Berdasarkan laporan keuangan PT Perusahaan Gas Negara (Persero) Tbk tahun 2015 sampai 2017 yaitu Laporan Posisi Keuangan dan Laporan Laba Rugi, maka peneliti melakukan analisis terhadap rasio-rasio sesuai dengan Keputusan Menteri BUMN Nomor: KEP-100/MBU/2002. Indikator-indikator aspek keuangan adalah sebagai berikut:

\section{a) Imbalan kepada pemegang saham (ROE)}

Keputusan Menteri Badan Usaha Milik Negara Nomor 100/2002 menyatakan bahwa Imbalan kepada pemegang saham/Return On Equity (ROE) dapat dirumuskan sebagai berikut:

$$
\text { ROE }=\frac{\text { Laba Setelah Pajak }}{\text { Modal sendiri }} \times 100 \%
$$

Detail perhitungan imbalan kepada pemegang saham/Return On Equity (ROE) dari tahun 2015-2017 pada PT Perusahaan Gas Negara (Persero) Tbk adalah sebagai berikut :

Tahun $2015=\frac{402,758,904 \times 100 \%}{3,020,356,125}=13,33 \%$

Tahun $2016=\underline{308,583,916 \times 100 \%=9,75 \%}$ $3,163,174,709$

Tahun $2017=\underline{147,784,011 \times 100 \%=4,66 \%}$ $3,168,150,943$

\begin{tabular}{|c|c|}
\hline ROE (\%) & SKOR \\
\hline & NON INFRA \\
\hline $15<\mathrm{ROE}$ & 20 \\
\hline $13<\mathrm{ROE}<=15$ & 18 \\
\hline $11<\mathrm{ROE}<=13$ & 16 \\
\hline $9<\mathrm{ROE}<=11$ & 14 \\
\hline $7,9<\mathrm{ROE}<=9$ & 12 \\
\hline $6,6<\mathrm{ROE}<=7,9$ & 10 \\
\hline $5,3<\mathrm{ROE}<=6,6$ & 8,5 \\
\hline $4<\mathrm{ROE}<=5,3$ & 7 \\
\hline $2,5<\mathrm{ROE}<=4$ & 5,5 \\
\hline $1<\mathrm{ROE}<=2,5$ & 4 \\
\hline $0<\mathrm{ROE}<=1$ & 2 \\
\hline $\mathrm{ROE}<0$ & 0 \\
\hline $\begin{array}{l}\text { Sumber: Keputusar } \\
\text { Milik } \quad \text { Negara }\end{array}$ & $\begin{array}{lr}\text { teri } & \text { Badan Us } \\
\text { nor } & 100 / 2\end{array}$ \\
\hline
\end{tabular}

Tabel 1. Daftar Skor Penilaian ROE

TABEL 2.

Hasil Perhitungan ROE PT Perusahaan Gas Negara (Persero) Tbk

\begin{tabular}{|l|l|l|l|l|}
\hline Tahun & $\begin{array}{l}\text { Laba Setelah Pajak } \\
\text { (USD) }\end{array}$ & $\begin{array}{l}\text { Modal Sendiri } \\
\text { (USD) }\end{array}$ & ROE (\%) & Skor \\
\hline 2015 & $402,758,904$ & $3,020,356,125$ & 13,33 & 18 \\
\hline 2016 & $308,583,916$ & $3,163,174,709$ & 9,7 & 14 \\
\hline 2017 & $147,784,011$ & $3,168,150,943$ & 4,6 & 7 \\
\hline
\end{tabular}




\section{b) Imbalan Investasi (ROI)}

Keputusan Menteri Badan Usaha

Milik Negara Nomor 100/2002 menyatakan bahwa Imbalan Investasi (ROI) dapat dirumuskan sebagai berikut:

$\mathrm{ROI}=\frac{\text { EBIT }+ \text { Penyusutan }}{\text { Capital Employed }} \times 100 \%$

Definisi:
EBIT adalah laba sebelum pajak dan beban bunga

Capital Employed adalah total aktiva dikurangi aktiva tetap dalam perjalanan

Detail perhitungan imbalan investasi/Return On Investment (ROI) dari tahun 2015-2017 pada PT Perusahaan Gas Negara (Persero) Tbk adalah sebagai berikut:

Tahun $2015=\underline{437,364,583+119,162,853+1,203,936,074} \times 100 \%=29,4 \%$ $6,495,022,261-505,108,402$

Tahun $2016=\underline{384,985,146+132,404,898+1,346,504,315} \times 100 \%=29,5 \%$ $6,834,152,968-516,900,607$

Tahun $2017=\underline{275,550,022+147,175,165+1,544,363,326} \times 100 \%=32,3 \%$ $6,293,128,991-213,015,522$

Tabel 3. Daftar Skor Penilaian ROI

\begin{tabular}{|c|c|}
\hline \multirow{2}{*}{$\mathrm{ROI}(\%)$} & SKOR \\
\cline { 2 - 2 } & NON INFRA \\
\hline $18<\mathrm{ROI}$ & 15 \\
\hline $15<\mathrm{ROI}<=18$ & 13,5 \\
\hline $13<\mathrm{ROI}<=15$ & 12 \\
\hline $12<\mathrm{ROI}<=13$ & 10,5 \\
\hline $10,5<\mathrm{ROI}<=12$ & 9 \\
\hline $9<\mathrm{ROI}<=10,5$ & 7,5 \\
\hline $7<\mathrm{ROI}<=9$ & 6 \\
\hline $5<\mathrm{ROI}<=7$ & 5 \\
\hline $3<\mathrm{ROI}<=5$ & 4 \\
\hline $1<\mathrm{ROI}<=3$ & 3 \\
\hline $0<\mathrm{ROI}<=1$ & 2 \\
\hline $\mathrm{ROI}<0$ & 1 \\
\hline
\end{tabular}

Sumber : Keputusan Menteri Badan Usaha Milik Negara Nomor 100/2002

TABEL 4

Hasil Perhitungan ROI PT Perusahaan Gas Negara (Persero) Tbk

\begin{tabular}{|c|c|c|c|c|}
\hline Tahun & $\begin{array}{c}\text { Total EBIT \& } \\
\text { Penyusutan (USD) }\end{array}$ & $\begin{array}{c}\text { Total Capital } \\
\text { Employed (USD) }\end{array}$ & ROI (\%) & Skor \\
\hline 2015 & $1,760,463,510$ & $5,989,913,859$ & 29,4 & 15 \\
\hline 2016 & $1,863,894,359$ & $6,317,252,361$ & 29,5 & 15 \\
\hline 2017 & $1,967,088,513$ & $6,080,113,469$ & 32,3 & 15 \\
\hline
\end{tabular}

c) Rasio Kas / Cash Ratio

Keputusan Menteri Badan Usaha Milik Negara Nomor 100/2002 menyatakan bahwa Rasio Kas/Cash Ratio dapat dirumuskan sebagai berikut: 
Cash Ratio $=$ Kas + Bank + Surat Berharga Jangka Pendek $\times 100 \%$ Current Liabilities

Detail perhitungan Rasio Kas/ Cash Ratio dari tahun 2015-2017 pada PT Perusahaan Gas Negara (Persero) Tbk adalah sebagai berikut:

Tahun $2015=\underline{1,200,171,560} \times 100 \%=179,8 \%$ $667,320,181$

Tahun $2016=\underline{1,372,876,021 \times 100 \%}=168,3 \%$ $815,371,887$

Tahun $2017=\frac{1,096,992,007 \times}{466,661,068} 100 \%=235,7 \%$
Tabel 5. Daftar Skor Penilaian Cash Ratio

\begin{tabular}{|c|c|}
\hline Cash Ratio (\%) & SKOR \\
\cline { 2 - 2 } & NON INFRA \\
\hline $\mathrm{x}>=35$ & 5 \\
\hline $25<=\mathrm{x}<35$ & 4 \\
\hline $15<=\mathrm{x}<25$ & 3 \\
\hline $10<=\mathrm{x}<15$ & 2 \\
\hline $5<=\mathrm{x}<10$ & 1 \\
\hline $0<=\mathrm{x}<5$ & 0 \\
\hline
\end{tabular}

Sumber : Keputusan Menteri Badan Usaha Milik Negara Nomor 100/2002

TABEL 6

Hasil Perhitungan Cash Ratio PT Perusahaan Gas Negara (Persero) Tbk

\begin{tabular}{|c|c|c|c|c|c|}
\hline Tahun & $\begin{array}{c}\text { Kas dan } \\
\text { Setara Kas } \\
\text { (USD) }\end{array}$ & $\begin{array}{c}\text { Investasi } \\
\text { Jangka Pendek } \\
\text { (USD) }\end{array}$ & $\begin{array}{c}\text { Kewajiban } \\
\text { Lancar } \\
\text { (USD) }\end{array}$ & $\begin{array}{c}\text { Cash } \\
\text { Ratio (\%) }\end{array}$ & Skor \\
\hline 2015 & $1,135,502,538$ & $64,669,022$ & $667,320,181$ & 179,8 & 5 \\
\hline 2016 & $1,304,043,250$ & $68,832,771$ & $815,371,887$ & 168,3 & 5 \\
\hline 2017 & $1,026,328,911$ & $70,663,096$ & $466,661,068$ & 235,7 & 5 \\
\hline
\end{tabular}

\section{d) Rasio Lancar / Current Ratio}

Keputusan Menteri Badan Usaha

Milik Negara Nomor 100/2002 menyatakan bahwa Current Ratio dapat dirumuskan sebagai berikut:

Current Ratio $=$ Current Asset $\times 100 \%$

$$
\text { Current Liabilities }
$$

Detail perhitungan Rasio Lancar/Current Ratio dari tahun 20152017 pada PT Perusahaan Gas Negara (Persero) Tbk adalah sebagai berikut:

Tahun $2015=1,222,530,837 \times 100 \%=258,12 \%$ $667,320,181$

Tahun $2016=2,124,674,229 \times 100 \%=260,57 \%$

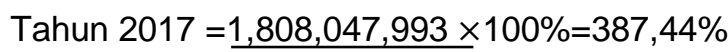
$466,661,068$

Tabel 7. Daftar Skor Penilaian Current Ratio

\begin{tabular}{|c|c|}
\hline $\begin{array}{c}\text { Current Ratio } \\
(\%)\end{array}$ & SKOR \\
\cline { 2 - 2 } & NON INFRA \\
\hline $125<=\mathrm{x}$ & 5 \\
\hline $110<=\mathrm{x}<125$ & 4 \\
\hline $100<=\mathrm{x}<110$ & 3 \\
\hline $95<=\mathrm{x}<100$ & 2 \\
\hline $90<=\mathrm{x}<95$ & 1 \\
\hline $\mathrm{x}<5$ & 0 \\
\hline
\end{tabular}

Sumber : Keputusan Menteri Badan Usaha Milik Negara Nomor 100/2002

TABEL 8

Hasil Perhitungan Current Ratio PT Perusahaan Gas Negara (Persero) Tbk

\begin{tabular}{|c|c|c|c|c|}
\hline Tahun & $\begin{array}{c}\text { Current Asset } \\
\text { (USD) }\end{array}$ & $\begin{array}{c}\text { Current Liabilities } \\
\text { (USD) }\end{array}$ & $\begin{array}{c}\text { Current } \\
\text { Ratio (\%) }\end{array}$ & Skor \\
\hline 2015 & $1,722,530,837$ & $667,320,181$ & 258,12 & 5 \\
\hline 2016 & $2,124,674,229$ & $815,371,887$ & 260,57 & 5 \\
\hline 2017 & $1,808,047,993$ & $466,661,068$ & 387,44 & 5 \\
\hline
\end{tabular}


e) Collection Periods (CP)

Keputusan Menteri Badan Usaha

Milik Negara Nomor 100/2002 menyatakan bahwa Collection Periods (CP) dapat dirumuskan sebagai berikut:

$\mathrm{CP}=\frac{\text { Total Piutang Usaha } \times 365 \text { hari }}{\text { Total Pendapatan Usaha }}$
Detail perhitungan Collection Periods (CP) dari tahun 2015-2017 pada PT Perusahaan Gas Negara (Persero) Tbk adalah sebagai berikut:

Tahun $2015=286,594,569 \times 365$ hari $=34,08$ hari $3,068,790,845$

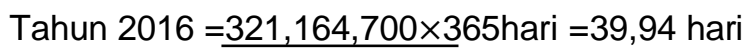
$2,934,778,710$

Tahun $2017=339,661,163 \times 365$ hari $=41,74$ hari $2,969,591,811$

Tabel 9. Daftar Skor Nilai Collection Periods

\begin{tabular}{|c|c|c|}
\hline \multirow[t]{2}{*}{$\mathrm{CP}=\mathrm{X}$ (hari) } & \multirow{2}{*}{$\begin{array}{c}\text { Perbaikan } \\
\text { (hari) }\end{array}$} & SKOR \\
\hline & & NON INFRA \\
\hline$x<=60$ & $x>=35$ & 5 \\
\hline $60<x<=90$ & $30<x<=35$ & 4,5 \\
\hline $90<x<=120$ & $25<x<=30$ & 4 \\
\hline $120<x<=150$ & $20<x<=25$ & 3,5 \\
\hline $150<x<=180$ & $15<x<=20$ & 3 \\
\hline $180<x<=210$ & $10<x<=15$ & 2,4 \\
\hline $210<x<=240$ & $6<x<=10$ & 1,8 \\
\hline $240<x<=270$ & $3<x<=6$ & 1,2 \\
\hline $270<x<=300$ & $1<x<=3$ & 0,6 \\
\hline $300<x$ & $0<x<=1$ & 0 \\
\hline
\end{tabular}

TABEL 10

Hasil Perhitungan Collection Periods PT Perusahaan Gas Negara (Persero) Tbk

\begin{tabular}{|c|c|c|c|c|c|c|}
\hline Tahun & $\begin{array}{c}\text { Total Piutang } \\
\text { Usaha (USD) }\end{array}$ & $\begin{array}{c}\text { Total } \\
\text { Pendapatan } \\
\text { Usaha (USD) }\end{array}$ & $\begin{array}{c}\text { Collection } \\
\text { Periods } \\
\text { (hari) }\end{array}$ & & Skor & \multicolumn{2}{|c|}{ Perbaikan } \\
\cline { 5 - 7 } & & & Selisih & Skor \\
\hline 2015 & $286,594,569$ & $3,068,790,845$ & 34,08 & 5 & 0 & 0 \\
\hline 2016 & $321,164,700$ & $2,934,778,710$ & 39,94 & 5 & 5,86 & 1,2 \\
\hline 2017 & $339,661,163$ & $2,969,591,811$ & 41,74 & 5 & 1,8 & 0,6 \\
\hline
\end{tabular}

\section{f) Perputaran Persediaan}

Keputusan Menteri Badan Usaha

Milik Negara Nomor 100/2002 menyatakan bahwa Perputaran Persediaan dapat dirumuskan sebagai berikut:

$$
\mathrm{PP}=\frac{\text { Total Persediaan }}{\text { Total Pendapatan Usaha }} \times 365 \text { hari }
$$

Detail perhitungan perputaran persediaan dari tahun 2015-2017 pada
PT Perusahaan Gas Negara (Persero) Tbk adalah sebagai berikut:

Tahun $2015=\underline{43,453,022 \times 365}$ hari $=5,17$ hari $3,068,790,845$

Tahun $2016=\frac{65,293,227 \times 365}{2934,778,710}$ hari $=8,12$ hari

Tahun $2017=\underline{60,820,710 \times 365}$ hari $=7,47$ hari $2,969,591,811$ 
Tabel 11. Daftar Skor Penilaian Perputaran Persediaan

\begin{tabular}{|c|c|c|}
\hline $\mathrm{CP}=\mathrm{x}$ (hari) & $\begin{array}{c}\text { Perbaikan }=\mathrm{x} \\
\text { (hari) }\end{array}$ & SKOR \\
\cline { 3 - 3 } & $\mathrm{NON}$ INFRA \\
\hline $\mathrm{x}<=60$ & $\mathrm{x}>=35$ & 5 \\
\hline $60<\mathrm{x}<=90$ & $30<\mathrm{x}<=35$ & 4,5 \\
\hline $90<\mathrm{x}<=120$ & $25<\mathrm{x}<=30$ & 4 \\
\hline $120<\mathrm{x}<=150$ & $20<\mathrm{x}<=25$ & 3,5 \\
\hline $150<\mathrm{x}<=180$ & $15<\mathrm{x}<=20$ & 3 \\
\hline $180<\mathrm{x}<=210$ & $10<\mathrm{x}<=15$ & 2,4 \\
\hline $210<\mathrm{x}<=240$ & $6<\mathrm{x}<=10$ & 1,8 \\
\hline $240<\mathrm{x}<=270$ & $3<\mathrm{x}<=6$ & 1,2 \\
\hline $270<\mathrm{x}<=300$ & $1<\mathrm{x}<=3$ & 0,6 \\
\hline $300<\mathrm{x}$ & $0<\mathrm{x}<=1$ & 0 \\
\hline
\end{tabular}

Sumber : Keputusan Menteri Badan Usaha Milik Negara Nomor 100/2002

TABEL 12

Hasil Perhitungan Perputaran Persediaan PT Perusahaan Gas Negara (Persero) Tbk

\begin{tabular}{|c|c|c|c|c|c|c|}
\hline Tahun & $\begin{array}{c}\text { Total } \\
\text { Persediaan } \\
\text { (USD) }\end{array}$ & $\begin{array}{c}\text { Potal } \\
\text { Pendapatan } \\
\text { Usaha (USD) }\end{array}$ & $\begin{array}{c}\text { Perputaran } \\
\text { Persediaan } \\
\text { (hari) }\end{array}$ & Skor & \multicolumn{2}{|c|}{$\begin{array}{c}\text { Perbaikan } \\
\text { (hari) }\end{array}$} \\
\cline { 5 - 7 } & Nilai & Skor \\
\hline 2015 & $43,453,022$ & $3,068,790,845$ & 5,17 & 5 & 0 & 0 \\
\hline 2016 & $65,293,227$ & $2,934,778,710$ & 8,12 & 5 & 2,95 & 0,6 \\
\hline 2017 & $60,820,710$ & $2,969,591,811$ & 7,47 & 5 & $-0,65$ & 0 \\
\hline
\end{tabular}

\section{g) Perputaran Total Asset/Total Asset Turn Over (TATO)}

Keputusan Menteri Badan Usaha

Milik Negara Nomor 100/2002 menyatakan bahwa Perputaran Total Asset/Total Asset Turn Over (TATO) dapat dirumuskan sebagai berikut:

$$
\text { TATO }=\frac{\text { Total Pendapatan }}{\text { Capital Employed }} \times 100 \%
$$

Detail perhitungan Perputaran Total Asset/Total Asset Turn Over (TATO) dari tahun 2015-2017 pada PT Perusahaan Gas Negara (Persero) Tbk adalah sebagai berikut:

Tahun $2015=3,068,790,845 \times 100 \%=51,2 \%$ $6,495,022,261-505,108,402$

Tahun $2016=2,934,778,710 \times 100 \%=46,4 \%$ $6,834,152,968-516,900,607$

Tahun $2017=2,969,591,81 \times 100 \%=48,8 \%$ $6,293,128,991-213,015,522$

Tabel 13. Skor Penilaian TATO

\begin{tabular}{|c|c|c|}
\hline TATO $=\mathrm{x}(\%)$ & $\begin{array}{c}\text { Perbaikan }= \\
\mathrm{x}(\%)\end{array}$ & SKOR \\
\cline { 3 - 3 } & $20<\mathrm{x}$ & 5 \\
\hline $120<\mathrm{x}$ & $15<\mathrm{x}<=20$ & 4,5 \\
\hline $105<\mathrm{x}<=120$ & 1 INFRA \\
\hline $90<\mathrm{x}<=105$ & $10<\mathrm{x}<=15$ & 4 \\
\hline $75<\mathrm{x}<=90$ & $5<\mathrm{x}<=10$ & 3,5 \\
\hline $60<\mathrm{x}<=75$ & $0<\mathrm{x}<=5$ & 3 \\
\hline $40<\mathrm{x}<=60$ & $\mathrm{x}<=0$ & 2,5 \\
\hline $20<\mathrm{x}<=40$ & $\mathrm{x}<0$ & 2 \\
\hline $\mathrm{x}<=20$ & $\mathrm{x}<0$ & 1,5 \\
\hline
\end{tabular}

Sumber : Keputusan Menteri Badan Usaha Milik Negara Nomor 100/2002 
TABEL 14.

Hasil Perhitungan Perputaran Total Aset/Total Asset Turn Over (TATO) PT Perusahaan Gas Negara (Persero) Tbk

\begin{tabular}{|c|c|c|c|c|c|c|}
\hline \multirow[t]{2}{*}{ Tahun } & \multirow{2}{*}{$\begin{array}{c}\text { Total } \\
\text { Pendapatan } \\
\text { (USD) }\end{array}$} & \multirow{2}{*}{$\begin{array}{l}\text { Total Capital } \\
\text { Employed } \\
\text { (USD) }\end{array}$} & \multirow{2}{*}{$\begin{array}{c}\text { TATO } \\
(\%)\end{array}$} & \multirow[t]{2}{*}{ Skor } & \multicolumn{2}{|c|}{ Perbaikan } \\
\hline & & & & & Nilai & Skor \\
\hline 2015 & $3,068,790,845$ & $5,989,913,859$ & 51,2 & 2,5 & 0 & 0 \\
\hline 2016 & $2,934,778,710$ & $6,317,252,361$ & 46,4 & 2,5 & $-4,8$ & 3 \\
\hline 2017 & $2,969,591,811$ & $6,080,113,469$ & 48,8 & 2,5 & 2,4 & 3 \\
\hline
\end{tabular}

\section{h) Rasio Total Modal Sendiri Terhadap Total Asset (TMS terhadap TA)}

Keputusan Menteri Badan Usaha Milik Negara Nomor 100/2002 menyatakan bahwa Rasio Total Modal Sendiri Terhadap Total Asset (TMS terhadap TA) dapat dirumuskan sebagai berikut:

TMS terhadap TA =

Total Modal Sendiri $\times 100 \%$ Total Asset
Detail perhitungan Rasio Total Modal Sendiri Terhadap Total Asset (TMS terhadap TA) dari tahun 20152017 pada PT Perusahaan Gas Negara (Persero) Tbk adalah sebagai berikut:

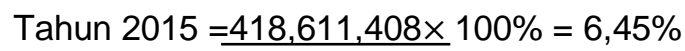
$6,495,022,261$

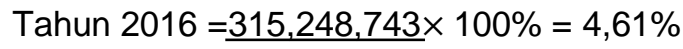
$6,834,152,968$

Tahun $2017=146,258.780 \times 100 \%=2,32 \%$ $6,293,128,991$

Tabel 15.

Skor Penilaian Total Modal Sendiri Terhadap Total Asset

\begin{tabular}{|c|c|}
\hline TMS terhadap TA & SKOR \\
\cline { 2 - 2 }$(\%)=\mathrm{x}$ & NON INFRA \\
\hline $\mathrm{x}<0$ & 0 \\
\hline $0<=\mathrm{x}<10$ & 4 \\
\hline $10<=\mathrm{x}<20$ & 6 \\
\hline $20<=\mathrm{x}<30$ & 7,25 \\
\hline $30<=\mathrm{x}<40$ & 10 \\
\hline $40<=\mathrm{x}<50$ & 9 \\
\hline $50<=\mathrm{x}<60$ & 8,5 \\
\hline $60<=\mathrm{x}<70$ & 8 \\
\hline $70<=\mathrm{x}<80$ & 7,5 \\
\hline $80<=\mathrm{x}<90$ & 7 \\
\hline $90<=\mathrm{x}<100$ & 6,5 \\
\hline
\end{tabular}

Sumber : Keputusan Menteri Badan Usaha Milik Negara Nomor 100/2002

TABEL 16

Hasil Perhitungan TMS terhadap TA PT Perusahaan Gas Negara (Persero) Tbk

\begin{tabular}{|c|c|c|c|c|}
\hline Tahun & $\begin{array}{c}\text { Total Modal } \\
\text { Sendiri (USD) }\end{array}$ & $\begin{array}{c}\text { Total Aktiva } \\
\text { (USD) }\end{array}$ & $\begin{array}{c}\text { TMS terhadap } \\
\text { TA (\%) }\end{array}$ & Skor \\
\hline 2015 & $418,611,408$ & $6,495,022,261$ & 6,45 & 4 \\
\hline 2016 & $315,248,743$ & $6,834,152,968$ & 4,61 & 4 \\
\hline 2017 & $146,258,780$ & $6,293,128,991$ & 2,32 & 4 \\
\hline
\end{tabular}


H. Pembahasan

Menurut KEP-MEN BUMN No. 100/MBU/2002 Penilaian Tingkat
Kesehatan BUMN digolongkan menjadi:

TABEL 17

Penilaian Tingkat Kesehatan BUMN

\begin{tabular}{|c|c|c|}
\hline Kategori & Total Skor & \multirow{2}{*}{ Keterangan } \\
\hline AAA & SEHAT \\
\hline AA & $80<95$ & \\
\hline$A$ & $65<T S<=95$ & \\
\hline BBB & $50<T S<=65$ & \multirow{2}{*}{ KURANG SEHAT } \\
\hline BB & $40<T S<=50$ & \\
\hline B & $30<T S<=40$ & \\
\hline CCC & $20<T S<=30$ & \multirow{2}{*}{ TIDAK SEHAT } \\
\hline CC & $10<T S<=20$ & \\
\hline C & $T S<=10$ & \\
\hline
\end{tabular}

TABEL 18

Total Skor Penilaian Kinerja Keuangan PT Perusahaan Gas Negara (Persero) Tbk

\begin{tabular}{|c|c|c|c|c|c|c|c|c|c|c|}
\hline Tahun & ROE & ROI & $\begin{array}{c}\text { Cash } \\
\text { Ratio }\end{array}$ & $\begin{array}{c}\text { Current } \\
\text { Ratio }\end{array}$ & CP & PP & TATO & $\begin{array}{c}\text { TMS } \\
\text { terhadap } \\
\text { TA }\end{array}$ & $\begin{array}{c}\text { Total } \\
\text { Skor }\end{array}$ & $\begin{array}{c}\text { Tingkat } \\
\text { Kesehatan }\end{array}$ \\
\hline 2015 & 18 & 15 & 5 & 5 & 5 & 5 & 2,5 & 4 & 59,5 & BBB \\
\hline 2016 & 14 & 15 & 5 & 5 & 5 & 5 & 2,5 & 4 & 55,5 & BBB \\
\hline 2017 & 7 & 15 & 5 & 5 & 5 & 5 & 2,5 & 4 & 48,5 & BB \\
\hline
\end{tabular}

Menurut KEPMEN BUMN No. 100/MBU/2002, pada tahun 2015 tingkat kesehatan PT Perusahaan Gas Negara (Persero) Tbk adalah BBB, yaitu kurang sehat. Hal tersebut terjadi dikarenakan rendahnya skor TATO yang mana ini berarti modal yang digunakan lebih besar daripada pendapatan perusahaan.

Pada tahun 2016 tigkat kesehatan PT Perusahaan Gas Negara (Pesrero) Tbk adalah BBB yang berarti kurang sehat. Skor tersebut dikarenakan ROE yang rendah. Yang berarti laba yang dihasilkan pada tahun 2016 lebih rendah dan modal yang digunakan cukup besar, sehingga membuat hasil ROE perusahaan menjadi rendah. Sedangkan hasil dari perhitungan yang lainnya cenderung stabil.

Pada tahun 2017 tingkat kesehatan perusahaan masih dalam kondisi yang kurang baik. Hal tersebut disebabkan skor ROE kembali menurun, yang berarti modal yang digunakan cukup besar sehingga laba yang dihasilkan pada tahun 2017 sangat rendah, sedangkan hasil yang lainnya cenderung stabil.

\section{Kesimpulan dan Saran \\ 1. Kesimpulan}

Menurut KEPMEN BUMN No. 100/MBU/2002, pada tahun 2015 sampai dengan tahun 2017 tingkat kesehatan PT Perusahaan Gas Negara (Persero) Tbk adalah KURANG SEHAT. Hal tersebut terjadi dikarenakan rendahnya skor TATO pada tahun 2015 yang mana ini berarti modal yang digunakan lebih besar daripada pendapatan perusahaan. Laba yang dihasilkan pada tahun 2016 lebih rendah dan modal yang digunakan cukup besar, sehingga membuat hasil ROE perusahaan menjadi rendah, dan hal tersebut tidak baik bagi perusahaan. Sedangkan pada tahun 2017 tingkat kesehatan 
perusahaan masih dalam kondisi yang kurang baik. Hal tersebut disebabkan skor ROE kembali menurun, yang berarti modal yang digunakan cukup besar sehingga laba yang dihasilkan pada tahun 2017 sangat rendah, sedangkan hasil dari perhitungan yang lainnya cenderung stabil.

\section{Saran}

Untuk dapat meningkatkan kinerja keuangan, PT Perusahaan Gas Negara (Persero) Tbk, peneliti memberikan beberapa saran sebagai berikut :

1. Dalam rangka meningkatkan laba, perusahaan seharusnya meningkatkan penjualan dan mengefisiensikan biaya operasional.

2. Sebaiknya perusahaan memaksimalkan penggunaan modal, sehingga bisa mendapatkan laba yang cukup besar.

\section{DAFTAR PUSTAKA}

Fahmi, Irham. 2014. Analisis Kinerja Keuangan. Alfabeta. Bandung.

Hery. 2015. Analisis Laporan Keuangan. CAPS (Center for Academic Publising Service). Jakarta.

http://ir.pgn.co.id/financial-information Diakses pada 3 Mei 2018

Jumingan. 2014. Analisis Laporan Keuangan. Bumi Aksara. Jakarta.
Kasmir. 2017. Analisis Laporan Keuangan. PT RajaGrafindo Persada. Jakarta.

Keputusan Menteri BUMN Nomor: KEP-100/MBU/2002 Tentang Penilaian Tingkat Kesehatan Badan Usaha Milik Negara.

Munawir. 2014. Analisis Laporan Keuangan. LibertyYogyakarta. Yogyakarta.

Nugrahanti, Triani. 2015. Analisis Rasio Keuangan Untuk Menilai Kinerja BUMN Pada PT Adhi Karya (Persero) Tbk. Skripsi. Fakultas Ekonomi Universitas Negeri Yogyakarta.

Prastowo, Dwi. 2015. Analisis Laporan keuangan. Sekolah Tinggi ilmu Manajemen YKPN. Yogyakarta.

Qolby, I.P. 2017. Analisis Kinerja Keuangan PT Semen Baturaja (Persero) Tbk. Skripsi. Fakultas Ekonomi Universitas Persatuan Guru Republik Indonesia Palembang.

Sugiyono. 2013. Metode Penelitian Kuantitatif Kualitatif dan R\&D. Alfabeta. Bandung.

Suryani dan Hendryadi. 2015. Metode Riset Kuantitatif. Prenadamedia Group. Jakarta.

www.Pgn.co.id/ tata-kelola Diakses pada 24 Mei 2018. 